\title{
Segment Polarity Protein Dishevelled Homolog DVL-1
}

National Cancer Institute

\section{Source}

National Cancer Institute. Segment Polarity Protein Dishevelled Homolog DVL-1. NCI

Thesaurus. Code C114516.

Segment polarity protein dishevelled homolog DVL-1 (695 aa, $75 \mathrm{kDa}$ ) is encoded by the human DVL1 gene. This protein plays a role in signal transduction. 